\title{
Tri-Cyclic Nucleobase Analogs and Their Ribosides as Substrates of Purine-Nucleoside Phosphorylases. II Guanine and Isoguanine Derivatives
}

\author{
Alicja Stachelska-Wierzchowska ${ }^{1, *}$, Jacek Wierzchowski ${ }^{1}$, Michał Górka ${ }^{2,3}{ }^{\mathbb{D}}$, \\ Agnieszka Bzowska ${ }^{2}$ and Beata Wielgus-Kutrowska ${ }^{2}$ (D) \\ 1 Department of Physics and Biophysics, University of Varmia \& Masuria in Olsztyn, 4 Oczapowskiego St., \\ 10-719 Olsztyn, Poland; jacek.wie@uwm.edu.pl \\ 2 Division of Biophysics, Institute of Experimental Physics, University of Warsaw, Pasteura 5, 02-093 Warsaw, \\ Poland; michal.gorka@fuw.edu.pl (M.G.); Agnieszka.Bzowska@fuw.edu.pl (A.B.); \\ Beata.Wielgus-Kutrowska@fuw.edu.pl (B.W.-K.) \\ 3 Biological and Chemical Research Centre, University of Warsaw, Żwirki i Wigury 101, 02-089 Warsaw, Poland \\ * Correspondence: alicja.stachelska@uwm.edu.pl; Tel.: +48-895-233-406; Fax: +48-895-233-861
}

Received: 6 March 2019; Accepted: 9 April 2019; Published: 16 April 2019

check for updates

\begin{abstract}
Etheno-derivatives of guanine, $O^{6}$-methylguanine, and isoguanine were prepared and purified using standard methods. The title compounds were examined as potential substrates of purine-nucleoside phosphorylases from various sources in the reverse (synthetic) pathway. It was found that $1, N^{2}$-etheno-guanine and $1, N^{6}$-etheno-isoguanine are excellent substrates for purine-nucleoside phosphorylase (PNP) from E. coli, while $\mathrm{O}^{6}$-methyl- $N^{2}, 3$-etheno-guanine exhibited moderate activity vs. this enzyme. The latter two compounds displayed intense fluorescence in neutral aqueous medium, and so did the corresponding ribosylation products. By contrast, PNP from calf spleens exhibited only modest activity towards $1, N^{6}$-etheno-isoguanine; the remaining compounds were not ribosylated by this enzyme. The enzymatic ribosylation of $1, N^{6}$-etheno-isoguanine using two forms of calf PNP (wild type and N243D) and E. coli PNP (wild type and D204N) gave three different products, which were identified on the basis of NMR analysis and comparison with the product of the isoguanosine reaction with chloroacetic aldehyde, which gave an essentially single compound, identified unequivocally as N9-riboside. With the wild-type E. coli enzyme as a catalyst, N9- $\beta$-D- and N7- $\beta$-D-ribosides are obtained in proportion $\sim 1: 3$, while calf PNP produced another riboside, tentatively identified as $N^{6}-\beta$-D-riboside. The potential application of various forms of PNP for synthesis of the tri-cyclic nucleoside analogs is discussed.
\end{abstract}

Keywords: chemical mutagenesis; fluorescence; nucleobase/nucleoside analogs; purine nucleoside phosphorylase; tautomerism

\section{Introduction}

Some tri-cyclic analogs of the natural purine bases and their glycosides show intense fluorescence, what enables their application as fluorescent probes in the investigations of structure and function of nucleic acids (DNA, RNA) and enzymes related to nucleic acid metabolism or utilizing nucleotide cofactors [1,2]. The most popular probe of this kind is $1, N^{6}$-etheno-adenosine ( $\varepsilon$ Ado), easily produced in the reaction of adenosine with chloroacetic aldehyde (CAA) in aqueous environment.

Other etheno-purine derivatives (see Scheme 1) were also prepared but were reported to display rather discouraging emission properties: This refers to the guanine/guanosine derivatives [3-5], as well to the products of the analogous reactions of CAA with 2-aminopurine and its riboside [6,7], and 2,6-diaminopurine $[7,8]$, which were found to be only moderately fluorescent in the neutral aqueous 
medium. Nevertheless, a thorough spectral examination of those and other etheno-derivatives in various conditions seems to be necessary for further applications.

Tri-cyclic analogs and their ribosides are characterized by moderate biological activity, but some of them reveal promising anti-viral properties [9], recently reviewed by Janz-Wechmann et al. [10,11]. They are known to react with many enzymes of purine metabolism [2,10], and are important intermediates of the chemical mutagenesis [12].

In our laboratory, we are working on an enzyme purine-nucleoside phosphorylase (PNP, E.C. 2.4.2.1), responsible for the regulation of the various nucleosides concentrations within the living cells, and a target of many types of pharmaceutical interventions [13,14]. It is also utilized as a biocatalyst in chemo-enzymatic syntheses of nucleoside analogs of pharmaceutical significance [15-17]. Until recently it was presumed that this enzyme is not active towards the tri-cyclic analogs (bases or nucleosides). This conclusion was drawn from the early experiments made in the 80s [2], which however could not take into account a great variety of the molecular forms of this enzyme known today $[13,17]$.

Our introductory investigations have shown that PNP isolated from E. coli, which is known to possess a broad specificity toward various base and nucleoside analogs [13], is also active towards tri-cyclic $\varepsilon$ Ado and its 2-aza analog [18]. The phosphorolytic reaction of $\varepsilon$ Ado was almost as rapid as other phosphorolytic reactions with natural substrates, like adenosine or guanosine. In the absence of phosphate ions, it is possible to observe the reverse reaction, that is, attachment of the sugar moiety to the tri-cyclic base, where the second substrate is a phosphorylated sugar (in our case $\alpha$-D-ribose-1-phosphate, R1P). This reaction runs similarly rapidly as the phosphorolytic process.

The purpose of the present work was to examine other similar tri-cyclic nucleobase analogs, in particular guanine and isoguanine derivatives, as potential substrates of analogous reactions, and possibly obtain in this way highly fluorescent compounds, useful for the future research. We have also extended the spectral examination of the above-mentioned etheno-derivatives to include the respective ionic forms, which in some cases are important intermediates in enzymatic catalysis, occasionally identified in enzyme-substrate complexes [19].<smiles>O=c1c2nc[nH]c2[nH]c2nccn12</smiles>

(1)<smiles>O=C1c2nc[nH]c2-n2ccnc21</smiles>

(2)<smiles>COc1nc2nccn2c2[nH]cnc12</smiles>

(3)<smiles></smiles>

(4)

Scheme 1. Structures of the nucleobase analogs investigated in this work (from left to right): (1) 1, $N^{2}$-ethenoguanine, (2) $N^{2}$,3-ethenoguanine, (3) $N^{2}, 3$-etheno- $O^{6}$-methylguanine, (4) $1, N^{6}$-ethenoisoguanine. Only one tautomeric form is given for simplicity. Note that the purine numbering is applied (except for the etheno-group atoms).

\section{Results and Discussion}

\subsection{Properties of $1, N^{2}$-ethenoguanine and $1, N^{2}$-ethenoguanosine}

$1, N^{2}$-ethenoguanine (1,5,9-dihydro-9-oximidazo\{1,2-a\}purine) is one of 2 isomeric etheno derivatives of guanine, its structure similar to one of the known rare t-RNA bases, the so-called Y-base (3,10-dimethyl-1, $N^{2}$-ethenoguanine) [3]. 1, $N^{2}$-ethenoguanine is a main product of the slow reaction of CAA with guanine [5], and one of three main products of the reaction of DNA with the mutagen vinyl chloride [12,20-22]. We decided that more convenient way to obtain this isomer would be a much faster reaction of CAA with 2-amino-6-chloropurine riboside [6], which gave a mixture 
of etheno-guanine isomers and some ribosides as well, readily separated using semi-preparative high-performance liquid chromatography (HPLC).

$1, N^{2}$-ethenoguanine (1) was reported to be nonfluorescent in the neutral aqueous medium [3]. Weak emission was observed from its monoanionic form (Table 1), but no significant emission was detected at low $\mathrm{pH}(\sim 1)$, where this compound is protonated.

Table 1. Ionization constants ( $\mathrm{pK}_{\mathrm{a}}$ values) and spectral parameters of neutral and ionic forms* of the investigated compounds. The UV spectral data are compiled from refs [1-3], and checked in this work, and fluorescence parameters determined in this work, except those for $N^{2}, 3$-ethenoguanine.

\begin{tabular}{|c|c|c|c|c|c|c|c|}
\hline \multirow{2}{*}{ Compound } & \multirow{2}{*}{$\begin{array}{l}\mathrm{pK}_{\mathrm{a}} \\
\pm 0.1\end{array}$} & \multirow{2}{*}{$\begin{array}{l}\text { Form* } \\
(\mathrm{pH})\end{array}$} & \multicolumn{2}{|c|}{ UV Absorption } & \multicolumn{3}{|c|}{ Fluorescence } \\
\hline & & & $\lambda_{\max }\{\mathrm{nm}\}$ & $\varepsilon_{\max }\left\{\mathrm{M}^{-1} \mathrm{~cm}^{-1}\right\}$ & $\lambda_{\max }\{\mathrm{nm}\}$ & $\phi$ & $\tau\{$ ns $\}$ \\
\hline \multirow{4}{*}{$1, N^{2}$-ethenoguanine } & \multirow{3}{*}{$\begin{array}{c}\sim 2 \\
\sim 9.5\end{array}$} & n (6) & 287 & 9700 & - & - & - \\
\hline & & c (1) & 291 & $\sim 8600$ & - & - & - \\
\hline & & $\mathrm{ma}(11)$ & 303 & 7200 & $\sim 400$ & $<0.01$ & nd ** \\
\hline & \multirow{3}{*}{8.8} & $\mathrm{n}(6.5)$ & 284 & 11900 & - & - & - \\
\hline \multirow[t]{2}{*}{ N9- $\beta$-D-ribofuranosyl- } & & $\mathrm{c}(1)$ & nd & nd & - & - & - \\
\hline & & $\mathrm{ma}(11)$ & 307 & 8400 & $\sim 400$ & $<0.01$ & nd \\
\hline \multirow{3}{*}{$N^{2}$,3-ethenoguanine } & \multirow{3}{*}{$\begin{array}{l}\sim 2.5 \\
8.8\end{array}$} & $\mathrm{n}(6.5)$ & 261 & 12850 & 400 & 0.02 & 1.38 \\
\hline & & ma (11) & 266 & 11300 & - & - & - \\
\hline & & c (1) & 255 & 11500 & - & - & - \\
\hline \multirow{3}{*}{$\begin{array}{c}N^{2}, 3 \text {-etheno- } \\
O^{6} \text { methylguanine }\end{array}$} & \multirow{3}{*}{$\begin{array}{l}\sim 3.5 \\
\sim 9\end{array}$} & $\mathrm{n}(6.5)$ & 272 & 9900 & 405 & 0.11 & nd \\
\hline & & $c(2)$ & 268 & 13300 & 395 & 0.035 & nd \\
\hline & & $\mathrm{ma}(12)$ & 280 & 9100 & $\sim 380$ & $<0.01$ & nd \\
\hline \multirow{3}{*}{$\begin{array}{l}1, N^{6} \text {-etheno- } \\
\text { isoguanine }\end{array}$} & \multirow{3}{*}{$\begin{array}{l}3.5 \\
8.0\end{array}$} & $\mathrm{n}(6.5)$ & 292 & 7000 & 415 & 0.17 & $5.15 ; 3.4$ \\
\hline & & $c(2)$ & 296 & 7300 & 385 & 0.44 & nd \\
\hline & & $\mathrm{ma}(11)$ & 290 & 6900 & 350 & $\sim 0.01$ & nd \\
\hline \multirow{4}{*}{ N9- $\beta$-D-ribofuranosyl- } & \multirow{3}{*}{$\begin{array}{l}2.4 \\
7.1\end{array}$} & $\mathrm{n}(5.5)$ & 295 & 7200 & 415 & 0.34 & 6.1 \\
\hline & & c (1.3) & 294 & $\sim 7000$ & 380 & 0.275 & $4.4 ; 0.81$ \\
\hline & & $\mathrm{ma}(11)$ & 281 & $\sim 7400$ & - & $<0.01$ & nd \\
\hline & \multirow{3}{*}{$\begin{array}{r}2.8 \\
\sim 8.5\end{array}$} & $\mathrm{n}(6)$ & 294 & 7100 & 360 & 0.036 & $0.8 ; 5.2$ \\
\hline \multirow[t]{2}{*}{ N7- $\beta$-D-ribofuranosyl- } & & $c(2)$ & 301 & $\sim 7200$ & 355 & $\sim 0.4$ & 3.5 \\
\hline & & ma (9) & 297 & $\sim 6500$ & 365 & $\sim 0.2$ & nd \\
\hline \multirow{3}{*}{$N^{6}$ - $\beta$-D-ribofuranosyl- } & \multirow{3}{*}{$\begin{array}{r}\sim 3 \\
\sim 8.5\end{array}$} & $\mathrm{n}(6.5)$ & 303 & 6900 & 425 & 0.66 & nd \\
\hline & & с (1.7) & 298 & nd & 405 & 0.82 & nd \\
\hline & & $\mathrm{ma}(11)$ & 312 & nd & 450 & $\sim 0.03$ & nd \\
\hline
\end{tabular}

*n-neutral form; c-cation; ma-monoanion; ${ }^{* *}$ nd-not determined.

We found that this compound is an excellent substrate for PNP from E. coli (Figure 1a), with catalytic and Michaelis' constants comparable to that for ribosylation of the parent guanine (Table 2). HPLC analysis of the reaction mixture has shown that there is one main product $(>95 \%)$, spectrally and chromatographically identical to the nucleoside generated in the chemical way (Figure 1). The reverse reaction (phosphorolysis of the nucleoside) is also easily observed in the presence of phosphate ions (Figure 1b). These facts may be important in view of a significant mutagenic role of $1, N^{2}$-ethgenoguanine (1) lesion in many organisms, particularly in bacteria [22].

The mutated form of the E. coli PNP (D204N) reacted in a qualitatively similar way as the wild-type enzyme, with similar spectral changes and comparable rate.

With the calf enzyme (wild-type or the N243D mutant) only very slow reaction was observed under typical conditions ( $\mathrm{pH}$ 7.3, 4-(2-hydroxyethyl)-1-piperazineethanesulfonic acid (HEPES) buffer, $25^{\circ} \mathrm{C}$ ). This reaction was ca. 100 -fold slower than the ribosylation of guanine. There was also no marked phosphorolysis of the nucleoside by this enzyme in the phosphate buffer (data not shown). We conclude that PNP probably does not play any substantial role in the process of detoxication of etheno-guanosine in mammals, but this kind of degradation can be important in bacteria. 


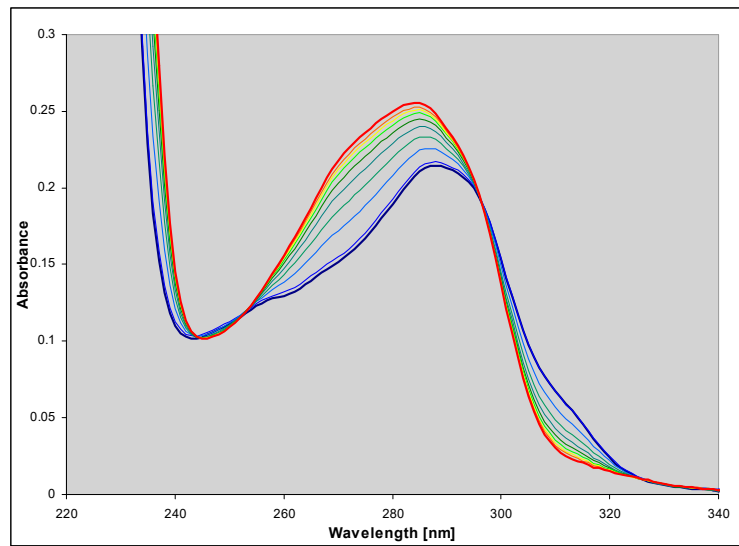

(a)

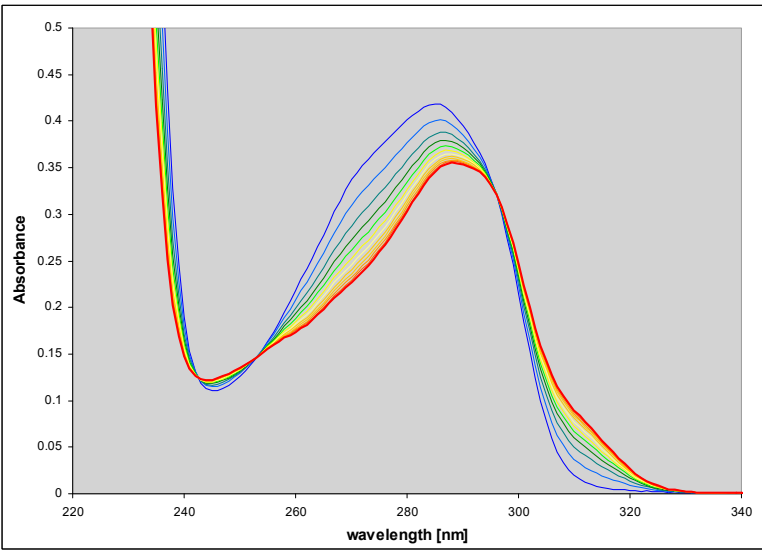

(b)

Figure 1. Spectral changes observed during (a) the enzymatic ribosylation of $1, N^{2}$-ethenoguanine (1) with $0.5 \mathrm{mM}$ R1P, in HEPES buffer, pH 7.3, catalyzed by purine-nucleoside phosphorylase (PNP) from E. coli; (b) enzymatic phosphorolysis of $1, N^{2}$-ethenoguanosine by the same enzyme in $50 \mathrm{mM}$ phosphate buffer, $\mathrm{pH}$. The time interval is $5 \mathrm{~min}$. Final curves are drawn in red.

Table 2. Kinetic parameters for the enzymatic ribosylation of nucleobase analogs investigated in this work, in $40 \mathrm{mM}$ HEPES buffer, $\mathrm{pH}$ 7, by $\alpha$-D-ribose-1-phosphate, using various forms of PNP (wt = wild type). Standard errors are estimated to be $\sim 15 \%$.

\begin{tabular}{|c|c|c|c|}
\hline Substrate/Enzyme & $\begin{array}{c}\mathrm{K}_{\mathrm{m}} \\
(\mu \mathrm{M})\end{array}$ & $\underset{\text { (relative) }}{\mathrm{V}_{\text {max }}}$ & $\begin{array}{l}\text { Approximate Product Ratio: } \\
\text { N9: N7-riboside: } N^{6} \text {-riboside }\end{array}$ \\
\hline $\begin{array}{l}\text { 1, } N^{2} \text {-ethenoguanine } \\
\text { /calf PNP-wt** }\end{array}$ & nd & $<0.5$ & predominantly N9 \\
\hline $\begin{array}{l}\text { 1,N2-ethenoguanine } \\
\text { /calf PNP-mutantN243D }\end{array}$ & nd & - & - \\
\hline $\begin{array}{l}\text { 1, } N^{2} \text {-ethenoguanine } \\
\text { /E.coli PNP-wt }\end{array}$ & 48 & 18 & predominantly $N 9$ \\
\hline $\begin{array}{l}\text { 1, } N^{2} \text {-ethenoguanine } \\
\text { /E.coli PNP-mutantD204N }\end{array}$ & nd & $>15$ & predominantly $N 9$ \\
\hline $\begin{array}{c}N^{2}, 3 \text {-ethenoguanine } \\
\text { /calf PNP-wt }\end{array}$ & - & $<0.1$ & - \\
\hline $\begin{array}{c}N^{2}, 3 \text {-ethenoguanine } \\
\text { /E.coli PNP-wt }\end{array}$ & - & $<0.1$ & - \\
\hline $\begin{array}{c}N^{2}, 3 \text {-etheno- } O^{6} \text {-methylguanine } \\
\text { /calf PNP-wt }\end{array}$ & - & $<0.1$ & - \\
\hline $\begin{array}{c}N^{2}, 3 \text {-etheno- } O^{6} \text {-methylguanine } \\
\text { /E.coli PNP-wt }\end{array}$ & $\sim 6$ & $\sim 0.3$ & $\mathrm{Nd}$ \\
\hline $\begin{array}{c}\text { 1, } N^{6} \text {-ethenoisoguanine } \\
\text { /calf PNP-wt }\end{array}$ & $\sim 160$ & 1.6 & $1: 1: 10$ \\
\hline $\begin{array}{l}\text { 1,N6-ethenoisoguanine } \\
\text { /calf PNP- mutantN243D }\end{array}$ & nd & $\sim 1$ & predominantly $N^{6}$ \\
\hline $\begin{array}{l}\text { 1,N } N^{6} \text {-ethenoisoguanine } \\
\text { /E.coli PNP-wt }\end{array}$ & 98 & $\sim 24$ & 1:4:0.1 \\
\hline $\begin{array}{l}\text { 1,N6-ethenoisoguanine } \\
\text { /E.coli PNP-mutantD204N }\end{array}$ & nd & $>5$ & $5: 5: 0$ \\
\hline
\end{tabular}

${ }^{*}$ relative to $\mathrm{V}_{\max }$ of guanine ribosylation under the same conditions $(=100)$; error $\sim 10 \%$; ${ }^{* *} \mathrm{wt}=$ wild type.

\subsection{Spectral Properties of $N^{2}, 3-e t h e n o g u a n i n e$}

$N^{2}$,3-ethenoguanine (2), a non-linear isomer of $1, N^{2}$-ethgenoguanine (1), is a common and the most persistent lesion in DNA upon treatment with vinyl chloride [12]. Its role in mutagenesis has 
been addressed in many papers and shown to be significant [23-25]. This compound is weakly fluorescent in the neutral aqueous medium and moderately in some organic solvents [3]. The UV absorption of $N^{2}, 3$-ethenoguanine (2) is blue-shifted relative to $1, N^{2}$-ethenoguanine (1) (Figure 2), but its acido-basic properties are similar to those of the latter compound (Table 1), however, the ionic forms are nonfluorescent.

We found that $N^{2}$,3-ethenoguanine (2) is not a substrate for PNP form E. coli and calf spleen. No reaction traces were observed even with 10-fold higher enzyme concentrations than those applied to the synthesis of $1, N^{2}$-ethenoguanosine (see previous section). Ribosides of $N^{2}, 3$-ethenoguanine are known to be relatively unstable $[26,27]$, and ribose modifications stabilizing the glycosidic bond were used to study the role of this compound in mutagenesis [25]. Probably this instability of the glycoside bond is the main obstacle in its effective enzymatic ribosylation, although it is not clear why other possible ribosylation sites (like $N 7$ or $N^{2}$ ) cannot be utilized by the enzymes.

With guanine as a substrate of the ribosylation reaction, we have found moderate, possibly competitive inhibition of the E. coli PNP by $N^{2}, 3$-ethenoguanine (2), with estimated $\mathrm{K}_{\mathrm{i}}$ of $38 \mu \mathrm{M}$. This value is not far from the $\mathrm{K}_{\mathrm{m}}$ value for guanine (ca. $54 \mu \mathrm{M}$ in our conditions, [13]). We conclude that inability of the enzyme to ribosylate (2) is not due to geometric hindrance, but rather should be ascribed to unfavorable energetic factors, in accordance with previous reports about the relative instability of the glycosidic bond in this compound [23].

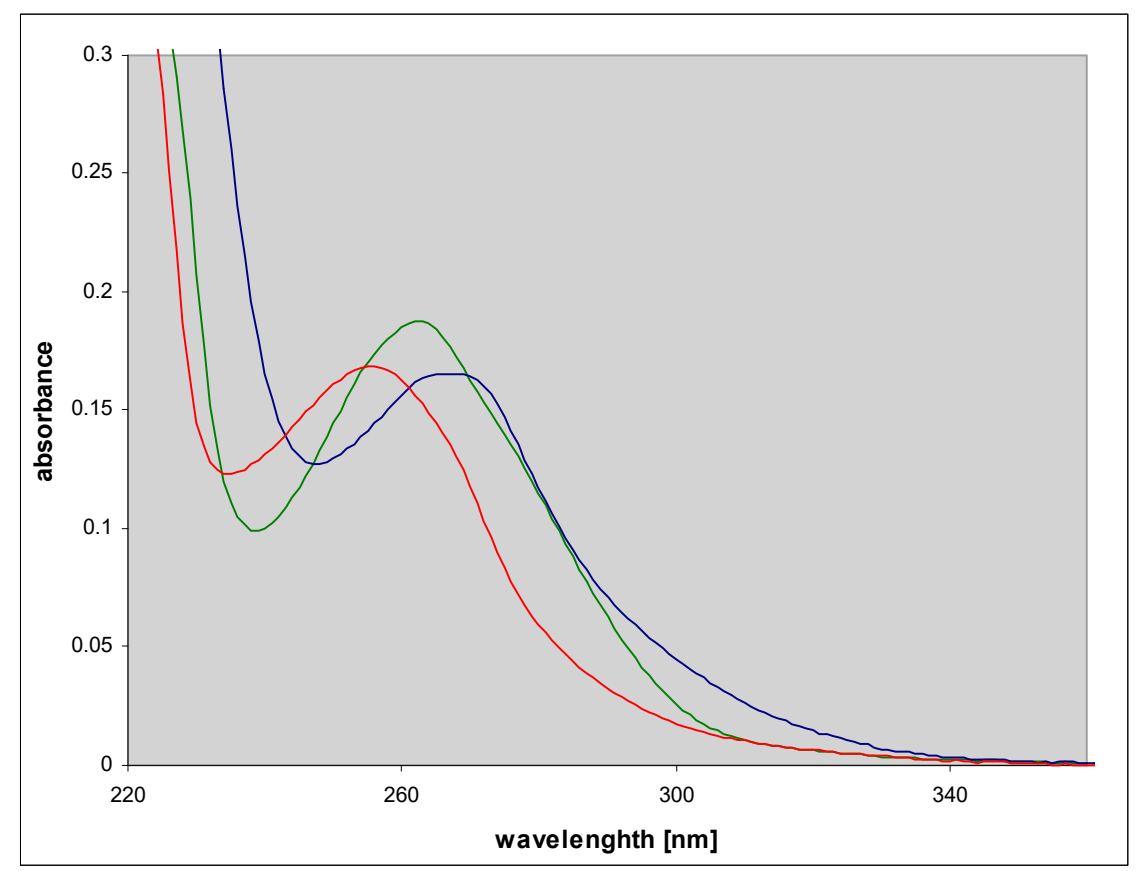

Figure 2. Electronic absorption spectra of the neutral (green), cationic (red) and mono-anionic forms of $N^{2}$,3-ethenoguanine (2).

\section{3. $N^{2}, 3-e$ theno-O ${ }^{6}$-methylguanine (3)}

A known mutagenic guanine derivative, $O^{6}$-methylguanine [26,27], reacts readily with CAA to give an essentially single product, identified as $N^{2}, 3$-etheno- $\mathrm{O}^{6}$-methylguanine (3) [3]. In contrast to the parent guanine derivative, this compound exhibits fairly intense fluorescence in neutral aqueous medium, centered about $400 \mathrm{~nm}$ (Figure 3 and Table 1). Its protonated form is also fluorescent, albeit with a lower yield, while the emission from the monoanionic form is only minimal (Figure 3 and Table 1). 


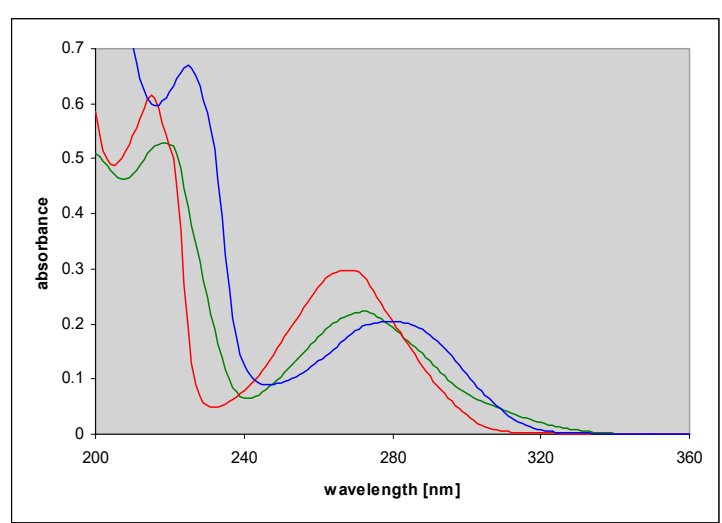

(a)

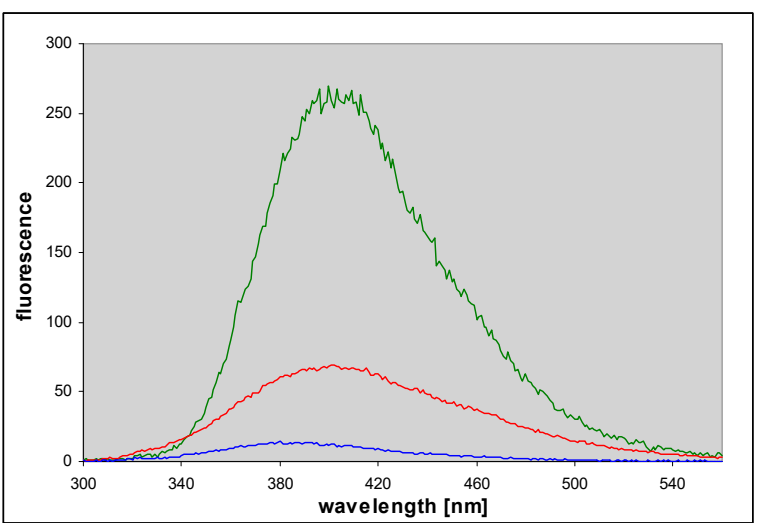

(b)

Figure 3. UV absorption (left) and fluorescence spectra (right) of $N^{2}, 3$-etheno- $O^{6}$-methylguanine at various pHs: Cationic form ( $\mathrm{pH} 2$, red), neutral ( $\mathrm{pH} 6.5$, green) and a monoanionic form ( $\mathrm{pH} 11, \mathrm{blue})$; excitation at $280 \mathrm{~nm}$.

$N^{2}, 3$-etheno- $O^{6}$-methylguanine (3) is also a substrate for PNP from E. coli, but the maximal velocity of its ribosylation is rather poor (Table 2). The product riboside spectrally differs from the substrate base, particularly by its weaker fluorescence, so the ribosylation is easy to follow (Figure 3). The reaction progress curve initially seems to be linear (Figure $4 \mathrm{~b}$, and Supplementary Materials), pointing to the low $\mathrm{K}_{\mathrm{m}}$ value. The observed marked differences in the absorption and emission spectra of the product riboside and the parent base is most likely due to prototropic tautomerism $(\mathrm{N} 9 \mathrm{H} \leftrightarrow \mathrm{N} 7 \mathrm{H})$ of the latter, not possible for the riboside.

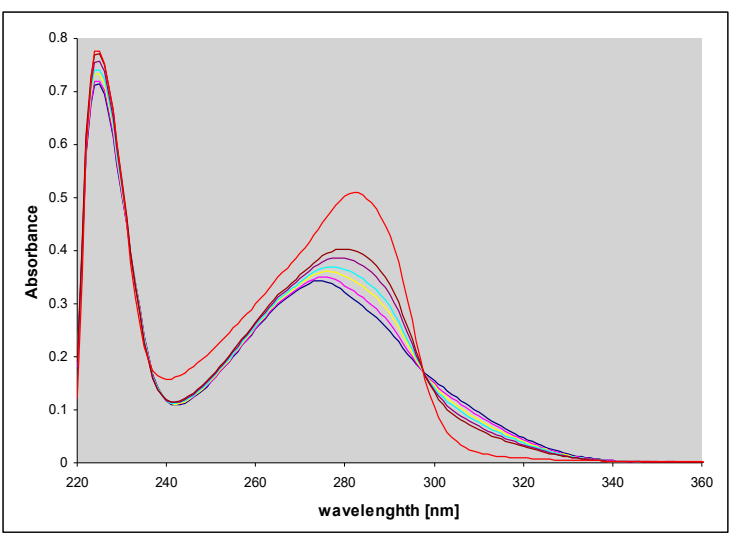

(a)

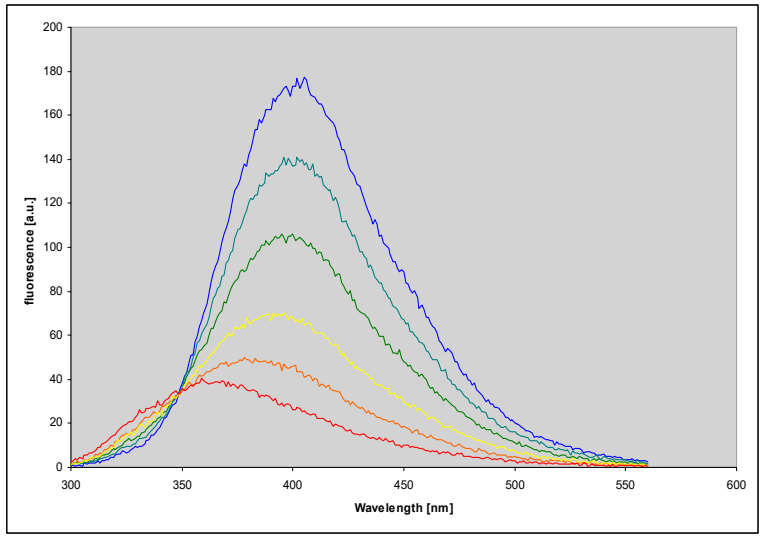

(b)

Figure 4. Spectral changes observed during the enzymatic ribosylation of $\sim 35 \mu \mathrm{M}$ $N^{2}$,3-etheno- $\mathrm{O}^{6}$-methylguanine (3) with E. coli PNP as a catalyst. (a): UV absorption; (b): Fluorescence spectra. Conditions: $40 \mathrm{mM}$ HEPES buffer, $\mathrm{pH} 7.3,0.5 \mathrm{mM}$ ribose-1-phosphate, $25^{\circ} \mathrm{C}$. The final (red) curves are recorded after ca. $24 \mathrm{~h}$ of reaction. Fluorescence excitation was taken at $280 \mathrm{~nm}$.

Although the ribosylation rate is slow, the apparent $\mathrm{K}_{\mathrm{m}}$ value, calculated from the progress curve (see Supplementary Materials), is markedly below $10 \mu \mathrm{M}$, so it is somewhat lower than that for the canonical nucleobases [13]. Although the kinetically measured $\mathrm{K}_{\mathrm{m}}$ cannot be directly used as a measure of binding properties of the purine analog [13], its low value indicates that the geometry of the compound is in this case not unfavorable for the E. coli PNP, and the confirms that the main reason for slow ribosylation and the resistance of the parent $N^{2}, 3$-ethenoguanine (3) to the enzymatic ribosylation is probably unfavorable energetics. 
The ribosylation reaction is fully reversible by the addition of a phosphate buffer up to a concentration of $\sim 5 \mathrm{mM}$ (even after $24 \mathrm{~h}$, data not shown). We did not attempt to isolate the pure riboside due to the low efficiency of the synthetic process, but it would be interesting to check the ribosylation site, which may be different from the "canonical" $N 9$, explaining spectral differences between this product and the parent base.

$\mathrm{N}^{2}, 3$-etheno- $\mathrm{O}^{6}$-methylguanine (3) effectively competes with guanine in the ribosylation process, acting as quasi inhibitor of the E. coli PNP, with estimated $\mathrm{K}_{\text {iapp }}$ value $7.5 \pm 0.8 \mu \mathrm{M}$ (competitive model; average of 3 determinations), in agreement with the $K_{m}$ value, estimated from kinetic data (see the previous paragraph). With the calf enzyme, no such inhibition is observed under similar conditions.

\section{4. $1, N^{6}$-etheno-isoguanine (4)}

Isoguanine (2-hydroxy-6-aminopurine, isoGua) is a guanine isomer, found in several living species [28], and it is also a product of adenine reaction with the hydroxyl radical, generated radiochemically [29]. Isoguanine and isoguanosine is characterized by the readily detectable, solvent-induced keto-enol tautomerism [28], and ambiguity of coding properties when incorporated into DNA/RNA [30].

The nucleoside of isoGua, isoguanosine, is rather slowly phosphorolysed by the E. coli PNP ( $\mathrm{V}_{\max }$ ca. 40-fold lower than that for guanosine, data not shown), and we did not see any such reaction catalyzed by the calf enzyme, in accordance with the general rule [13], that 6-aminopurine ribosides, not possessing mobile proton at the N1 position, do not react with trimeric forms of PNP, including mammalian enzymes.

Isoguanine reacts readily with CAA to produce a single, and highly fluorescent product, $1, N^{6}$-etheno-isoguanine ( $\varepsilon$ isoGua, (4)). The etheno-isoguanine fluorescence was long ago proposed as a tool for analytical quantitation of 9- $\beta$-D-arabinofuranosyl-2-fluoroadenine (fludarabine, [31]), but, to our knowledge, no systematic examination of the emission properties of eisoGua (4) exists in the literature. Basic spectral data for this compound are given in Table 1.

Spectrophotometric titrations of $\varepsilon$ isoGua (4) (for details, see the Supplementary Materials) indicate that this compound exists as a neutral species at $\mathrm{pH} 4.5-7$, and above $\mathrm{pH} 8$ undergoes deprotonation, and there is probably a second deprotonation at $\mathrm{pH} \sim 13$. The anionic forms are virtually nonfluorescent, while the neutral form and the cation are strongly fluorescent (Figure 5 and Table 1). Fluorimetric titrations give results essentially in agreement with the UV data (not shown).

Fluorescence properties of $\varepsilon$ isoGua (4) strongly suggest a ground-state tautomeric equilibrium. Fluorescence decay, measured at excitation $280 \mathrm{~nm}$ at pH 6.5 (neutral form), is clearly nonexponential, but well approximated by a bi-exponential decay function (data not shown), with decay times of 5.1 and 3.4 ns (see Table 1). Similar situations exist in $1, N^{6}$-adenine, but not its nucleoside [32]. Moreover, the fluorescence excitation spectrum of the neutral form of (4) at $\mathrm{pH} 6.5$, although virtually observation-independent (data not shown), is clearly distinct from the UV absorption (Figure 6 below), suggesting the existence of a third not-emitting or weakly emitting species. The tautomeric equillibria in $\varepsilon$ isoGua (4) are even more complex that those of etheno-adenine, where only a $N(9) \mathrm{H}-N(7) \mathrm{H}-N^{6} \mathrm{H}$ prototropic tautomerism is likely [18], while in (4) the situation is additionally complicated by possible keto-enol tautomerism (see Scheme 2, below). This problem requires therefore further elucidation.

$1, N^{6}$-etheno-isoguanine (4) is a moderately good substrate for PNP from various sources, but reactions with various types of the enzyme vary not only in rates but also in products obtained, giving at least 3 types of ribosides (Figures 7-9). This situation is somewhat reminiscent of the ribosylation of $1, N^{6}$-ethenoadenine, where also 3 ribosides were obtained [14,18], all of them fluorescent. In the case of (4), all three ribosylated species are also fluorescent, although with different yields and decay times (Table 1). 


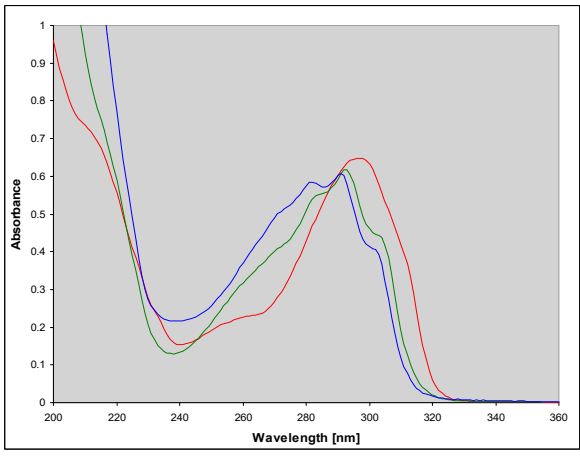

(a)

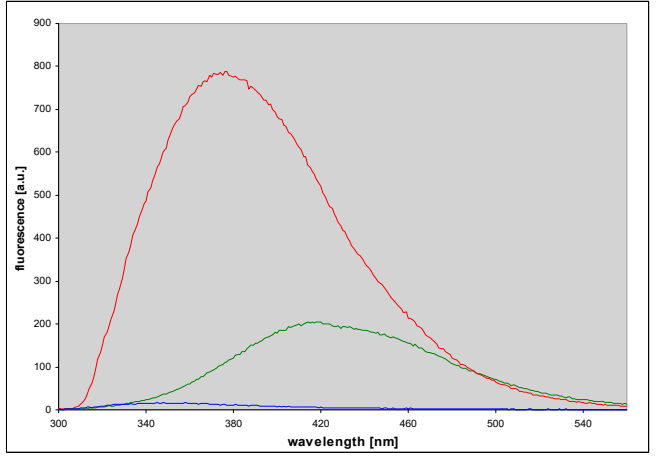

(b)

Figure 5. Electronic absorption (a) and fluorescence (b) spectra of $1, N^{6}$-etheno-isoguanine (4) in aqueous medium at various $\mathrm{pH}$ : Cationic form $(\mathrm{pH} 2$, red), neutral ( $\mathrm{pH}$ 6.5, green) and a monoanionic form ( $\mathrm{pH} 11$, blue). Fluorescence excitation was taken at $290 \mathrm{~nm}$.

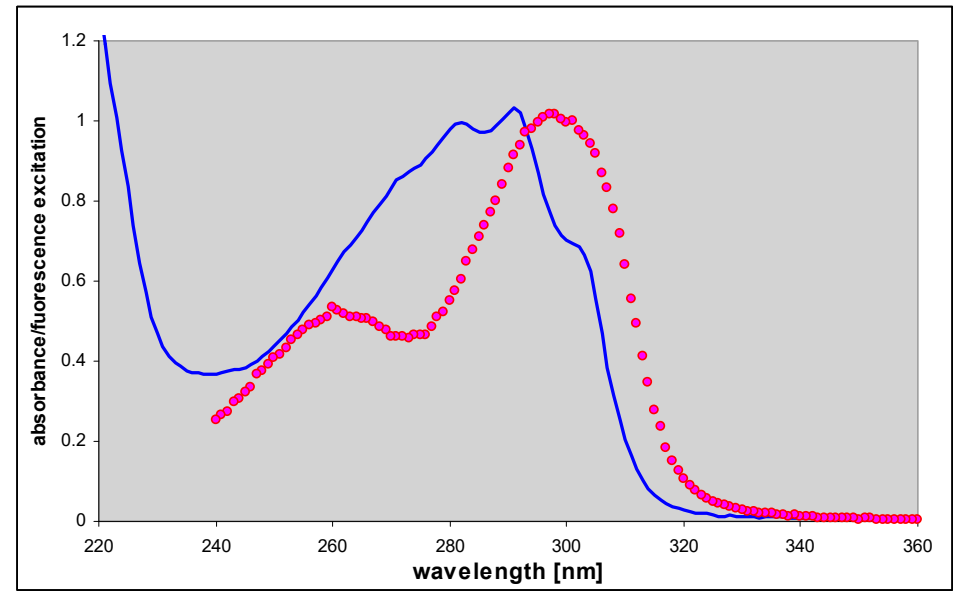

Figure 6. Comparison of the UV absorption (blue, solid line) and corrected fluorescence excitation (red points) spectrum of $1, N^{6}$-etheno-isoguanine (4), measured at $\mathrm{pH}$ 6.5. The fluorescence excitation spectrum was measured with observation at $415 \mathrm{~nm}$ and resolution $2.5 \mathrm{~nm}$.<smiles>Oc1nc2[nH]cnc2c2nccn12</smiles><smiles>O=c1[nH]c2[nH]cnc2c2nccn12</smiles><smiles>Oc1nc2nc[nH]c2c2nccn12</smiles><smiles>O=c1[nH]c2nc[nH]c2c2nccn12</smiles><smiles>Oc1nc2ncnc-2c2[nH]ccn12</smiles><smiles>O=c1nc2[nH]cnc2c2[nH]ccn12</smiles>

Scheme 2. Some of the possible tautomeric forms of $1, N^{6}$-etheno-isoguanine (4). 
Ribosides of $1, N^{6}$-etheno-isoguanine

As mentioned above, three types of ribosides of $1, N^{6}$-etheno-isoguanine (4) can be generated. One chemically from isoguanosine reacting with CAA, and all three enzymatically, using various types of PNP as a biocatalyst (Scheme 3). The reaction of isoguanosine with CAA was fairly rapid at $\mathrm{pH} 4.5$ and room temperature and gave essentially a single product, identified as N9- $\beta$-D-riboside (5) of $\varepsilon$ isoGua. Enzymatic ribosylation gave an additional 2 products, clearly not identical with (5). Ribosylation catalyzed by the enzyme from E. coli gave two products: The highly fluorescent N9-riboside (5, minor product), and another riboside with less intense fluorescence shifted to $\sim 355 \mathrm{~nm}$ (Figure 7 below, lower panels). The analogous reaction catalyzed by the calf PNP gave one main product, very intensely fluorescent, but with UV absorption spectrum markedly shifted to the longer wavelengths (Figure 7, upper panels). The observed ambiguity of the ribosylation sites is analogous to that described earlier for the enzymatic ribosylation of etheno-adenine [18] and some 8-azapurines [33].

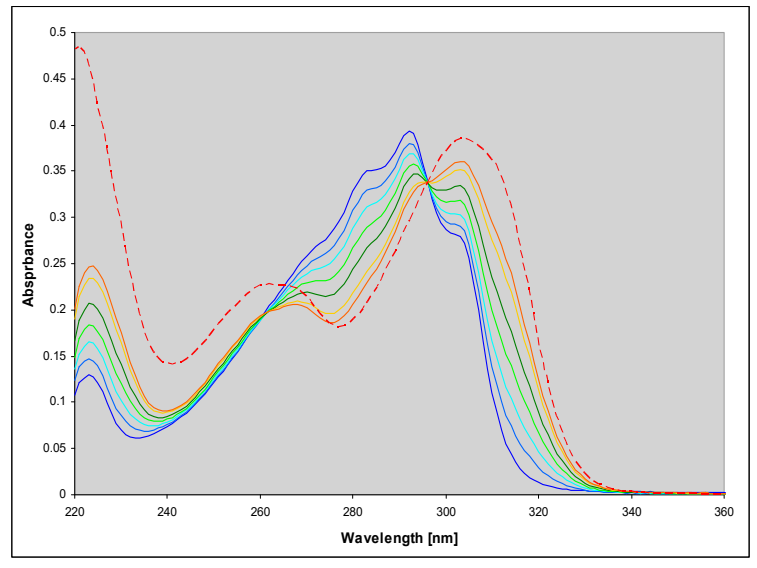

(a)

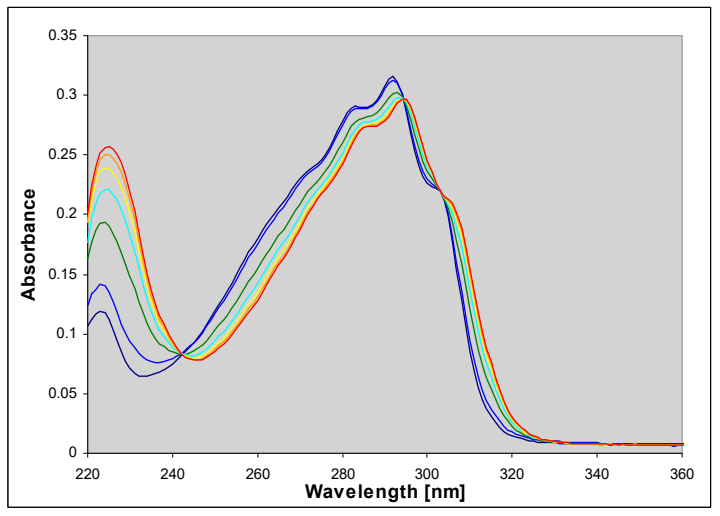

(c)

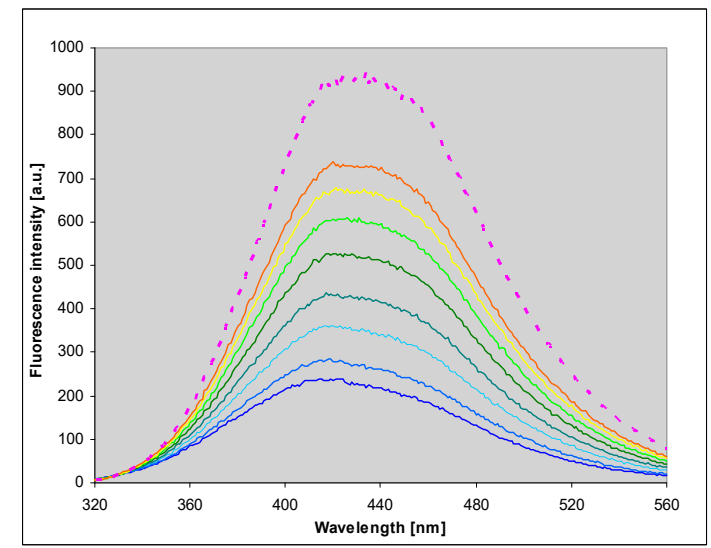

(b)

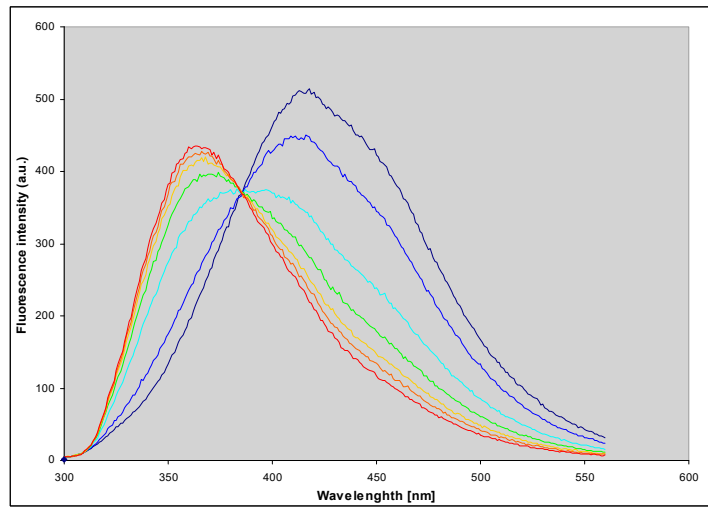

(d)

Figure 7. Changes in UV absorption $(\mathbf{a}, \mathbf{c})$ and fluorescence $(\mathbf{b}, \mathbf{d})$ spectra during the enzymatic ribosylation of $\varepsilon$ isoGua (4) with calf $(\mathbf{a}, \mathbf{b})$ and E. coli (c,d) PNP as catalysts. Excitation was at $290 \mathrm{~nm}$. Final curves are colored in red. The reactions were carried out in $40 \mathrm{mM} \mathrm{HEPES,} \mathrm{pH} \mathrm{7.3,} \mathrm{at} 25^{\circ} \mathrm{C}$, with $0.5 \mathrm{mM} \alpha$-D-ribose-1-phosphate as a ribosyl donor. Initial substrate concentrations in fluorescence measurements were $10-25 \mu \mathrm{M}$.

NMR spectral analysis was necessary to identify the ribosylation sites (Scheme 3). Identification of the three ribosides of isoGua (4) was based mainly on connectivities observed in ${ }^{1} \mathrm{H},{ }^{13} \mathrm{C} \mathrm{HMBC}$ 
spectra. ${ }^{1} \mathrm{H},{ }^{1} \mathrm{H}$ COSY spectra allowed for the assignment of all aliphatic sugar protons. Of the three signals of aromatic base protons, the two protons of the etheno group were identified due to the scalar coupling between them, with the $\varepsilon$ isoGua (4) H8 proton identified by elimination. The presence of $\mathrm{C} 8-\mathrm{H} 11^{\prime}$ and $\mathrm{C1}^{\prime}-\mathrm{H} 8$ correlations in the HMBC spectrum allowed for the identification of two of three samples as either N7 (6) or N9- (5) ribosides. The former riboside (6) was identified by the presence of $\mathrm{C} 6-\mathrm{H} 1$ ' and $\mathrm{C} 6-\mathrm{H} 8$ correlations, where $\mathrm{C} 6$ was assigned based on its relatively low chemical shift (typical values and the substituent effects have been reviewed in Reference [34]), compared to the expected chemical shift of C4. By elimination, the remaining sample was identified as the N9-riboside (5), in agreement with chemo-enzymatic identification provided in the previous paragraph. The $N^{6}$-riboside (7) was identified by the presence of the correlation of both etheno protons with $\mathrm{C}^{\prime}$ and (in the ${ }^{1} \mathrm{H},{ }^{15} \mathrm{~N}$ spectrum) $\mathrm{N}^{6}$. Selected chemical shifts are given in Table 3 , with the full list provided in Supplementary Materials.<smiles></smiles>

(5)<smiles>[R]n1cnc2[nH]c(=O)n3ccnc3c21</smiles>

(6)<smiles></smiles>

(7)

Scheme 3. Structures of the obtained ribosides of $1, N^{6}$-etheno-isoguanine (4). R= $\beta$-D-ribosyl: (5) $1, N^{6}$-etheno- $N 9$ - $\beta$-D-ribosylisoguanosine;

(6) $1, N^{6}$-etheno-N7- $\beta$-D-ribosylisoguanosine; $1, N^{6}$-etheno- $N^{6}$ - $\beta$-D-ribosylisoguanosine (7).

Table 3. Selected chemical shifts of the three ribosides of $\varepsilon$ isoGua. Chemical shift labels follow the naming convention of IUPAC-IUBMB-IUPAB [35], extended for the etheno protons (see Scheme 1). NA - resonance not assigned. For the N7- and N9-ribosides, atoms in the positions 10 and 11 could not be unequivocally differentiated, and the two possible values are slash-separated.

\begin{tabular}{|c|c|c|c|}
\hline \multirow{2}{*}{ Atom } & \multicolumn{3}{|c|}{ Sample/Chemical Shift (PPM) } \\
\hline & $N^{6}$-riboside & N7-riboside & N9-riboside \\
\hline $\mathrm{H} 1^{\prime}$ & 6.511 & 5.987 & 5.712 \\
\hline H8 & 7.822 & 8.262 & 7.753 \\
\hline $\mathrm{H} 10$ * & 7.775 & \multirow{2}{*}{$7.301 / 7.79$} & \multirow{2}{*}{$7.212 / 7.520$} \\
\hline $\mathrm{H} 11$ ** & 7.827 & & \\
\hline $\mathrm{C} 1^{\prime}$ & 90.293 & 89.833 & 89.114 \\
\hline $\mathrm{C} 5$ & NA & 104.600 & NA \\
\hline C6 & 138.682 & 137.918 & 141.788 \\
\hline $\mathrm{C} 8$ & 137.799 & 140.026 & 135.525 \\
\hline $\mathrm{C} 10$ & 113.386 & \multirow{2}{*}{$130.645 / 113.699$} & \multirow{2}{*}{ NA/111.558 } \\
\hline C11 & 116.951 & & \\
\hline
\end{tabular}

${ }^{*} \mathrm{H} 7$ or $\mathrm{C} 7$ according to IUPAC notation; ${ }^{* *} \mathrm{H} 8$ or C8 according to IUPAC notation. 
For (5) only one of the etheno protons is observable in $1 \mathrm{H}, 13 \mathrm{C}$ spectra, possibly due to (slow or intermediate) chemical exchange.

In the $50 \mathrm{mM}$ phosphate buffer, $\mathrm{pH}$ 6.5, the N9-riboside (5) is not phosphorolysed by the calf PNP, but the reaction with the E. coli enzyme is fairly rapid (see Supplementary Materials). Even more rapid is phosphorolysis of the N7-riboside (6) by the same type of PNP, while the $N^{6}$-riboside (7) is only slowly deribosylated by the calf enzyme, but much more rapidly by the E. coli PNP (data not shown). This is to be compared with $1, N^{6}$-ethenoadenosine, resistant to the calf enzyme, but rapidly phosphorolysed by the E. coli PNP [18]. All three ribosides are fairly stable in neutral aqueous environment, and no significant instability was seen at $\mathrm{pH} 11$ (data not shown). The respective emission yields of the neutral forms are comparable to those of the best-known fluorescent probes $[1,18,33,36]$. For these reasons, they seem to be more universal as probes than the somewhat unstable $1, N^{6}$-ethenoadenosine [1].

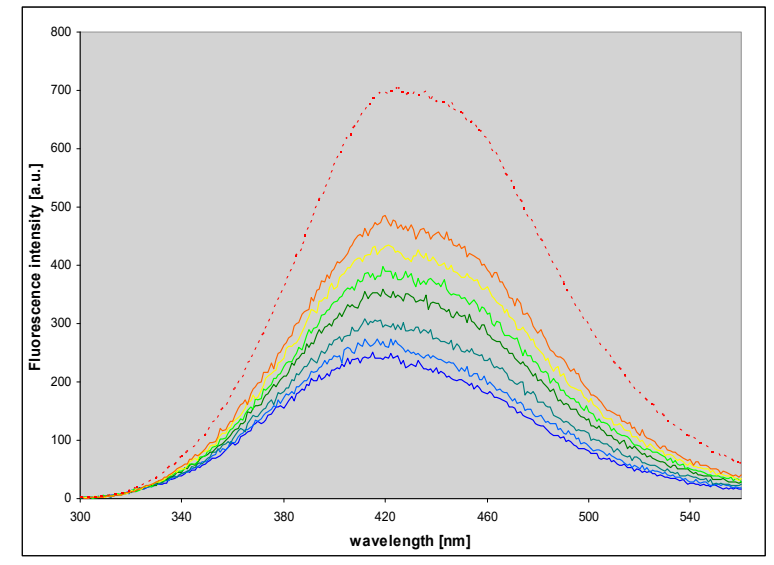

(a)

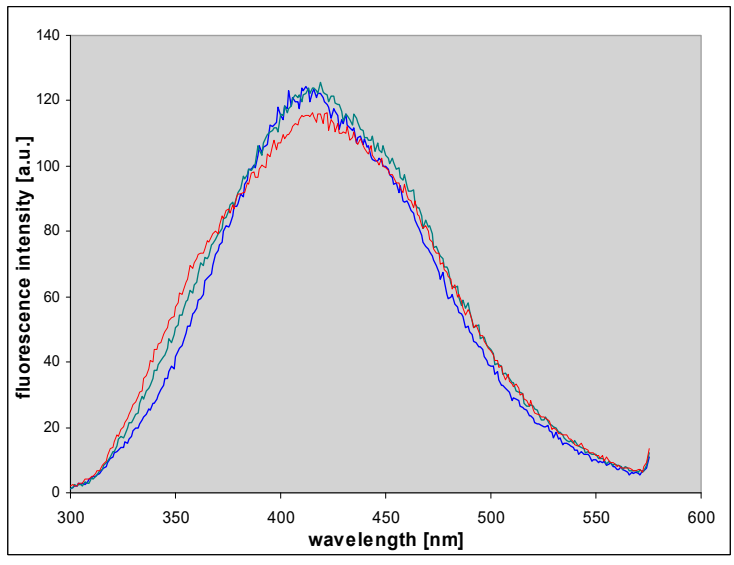

(b)

Figure 8. Changes in the fluorescence spectrum during the enzymatic ribosylation of $1, N^{6}$-etheno-isoguanine (4) by the mutated forms of PNP: (a), the N243D mutant of the calf PNP; (b): The D204N mutant of the E. coli enzyme. Final curves are colored in red. Initial substrate concentration was ca. $10 \mu \mathrm{M}$. Other reaction conditions were identical as on Figure 7. Excitation was taken at $290 \mathrm{~nm}$.

Various types of PNP mutated at the active site are known, some of them with qualitatively different catalytic characteristics $[33,37,38]$. We have therefore checked two of such mutants, namely the D204N mutant of the E. coli PNP and the "complementing" N243D mutant of the calf enzyme. Both mutations were previously shown to alter ribosylation specificity of PNP with 6-amino-purines [37] and 8 -azapurines $[33,38]$ as substrates.

In the case of $\varepsilon$ isoGua (4), the mutation effect is not very pronounced, with the exception of the E. coli PNP, where emission spectrum of the product mixture was shifted to the red, relative to the wild-type PNP reaction (Figures 7 and 8). This latter fact suggests a larger contribution by the N9-riboside (5) as a ribosylation product, with a possible contribution by other product(s). Reaction rates (catalytic constants) were comparable to those obtained for the wild-type enzymes. These results are analogous to those reported for $1, N^{6}$-ethenoadenine as a substrate [18]. 


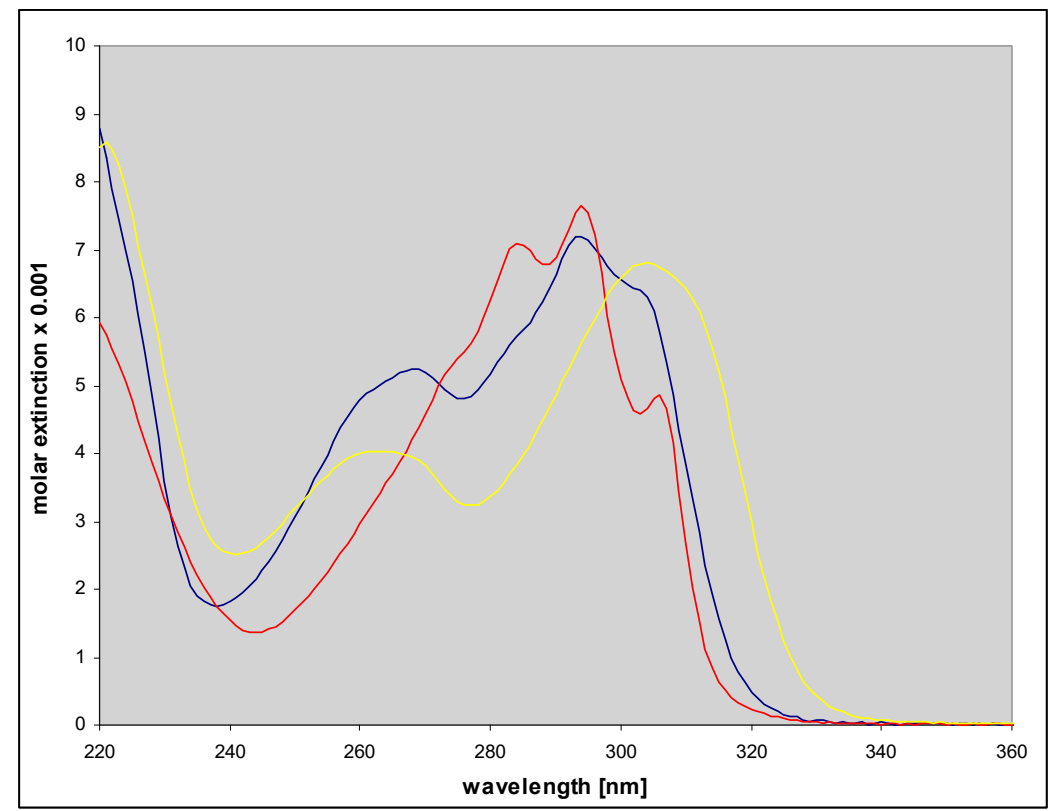

Figure 9. Electronic absorption spectra of three ribosides of $1, N^{6}$-etheno-isoguanine, purified by HPLC. Spectra of N9- (red color) and N7- $\beta$-D-riboside (blue) were measured in $50 \mathrm{mM}$ phosphate buffer, $\mathrm{pH}$ 6.5 , and that of $N^{6}$-riboside (yellow), at $\mathrm{pH} 7$.

\section{Experimental Section}

Isoguanine, isoguanosine, and their derivatives were obtained from Dr. Jerzy Sepiof (Polish Academy of Sciences). Chloroacetaldehyde, 7-methylguanosine, $O^{6}$-methylguanine and 2-amino-6-chloropurine riboside were from Sigma-Aldrich. The ribose source for enzymatic ribosylation, $\alpha$-D-ribose-1-phosphate (R1P) has been prepared as $100 \mathrm{mM}$ solution as previously described [18] and kept frozen.

Etheno-derivatives of guanine and guanosine were obtained analogously to Hořejši et al. [6], from the reaction of 2-amino-6-chloropurine riboside with ca 7-fold molar excess of chloroacetaldehyde (CAA, $[5,6])$. The reaction was carried out in aqueous environment, at room temperature and $\mathrm{pH} 4-4.5$, controlled by addition of sodium bicarbonate. After 3 days, the reaction mixture was acidified to $\mathrm{pH}$ $\sim 1$ and boiled by $\sim 3 \mathrm{~min}$. HPLC analysis (Figure 10) revealed a significant degree of hydrolysis of chloride, as well as of ribosyl moiety.

The main product was identified as $1, N^{2}$-ethenoguanine (1) on the basis of UV spectra in various conditions and lack of fluorescence. The second isomer, $N^{2}, 3$-ethenoguanine (2), was identified on the basis of its fluorescence and UV spectra shifted to $\sim 260 \mathrm{~nm}$. The third major product was $1, N^{2}$-ethenoguanosine, which was proved by its UV absorption and ready enzymatic phosphorolysis to $1, N^{2}$-ethenoguanine (1, see Section 2.1). Smaller amounts of guanine and the starting 2-amino-6-chloropurine riboside were also found. The main products were purified via the semi-preparative HPLC (C-18 column), eluted with water (10-12 min), followed by water-methanol gradient $(10-30 \%, 40 \mathrm{~min})$. The analogous method, with various reaction times, was used for other compounds (see below). The progress of the reactions was monitored spectrally or, wherever possible, also fluorimetrically. 


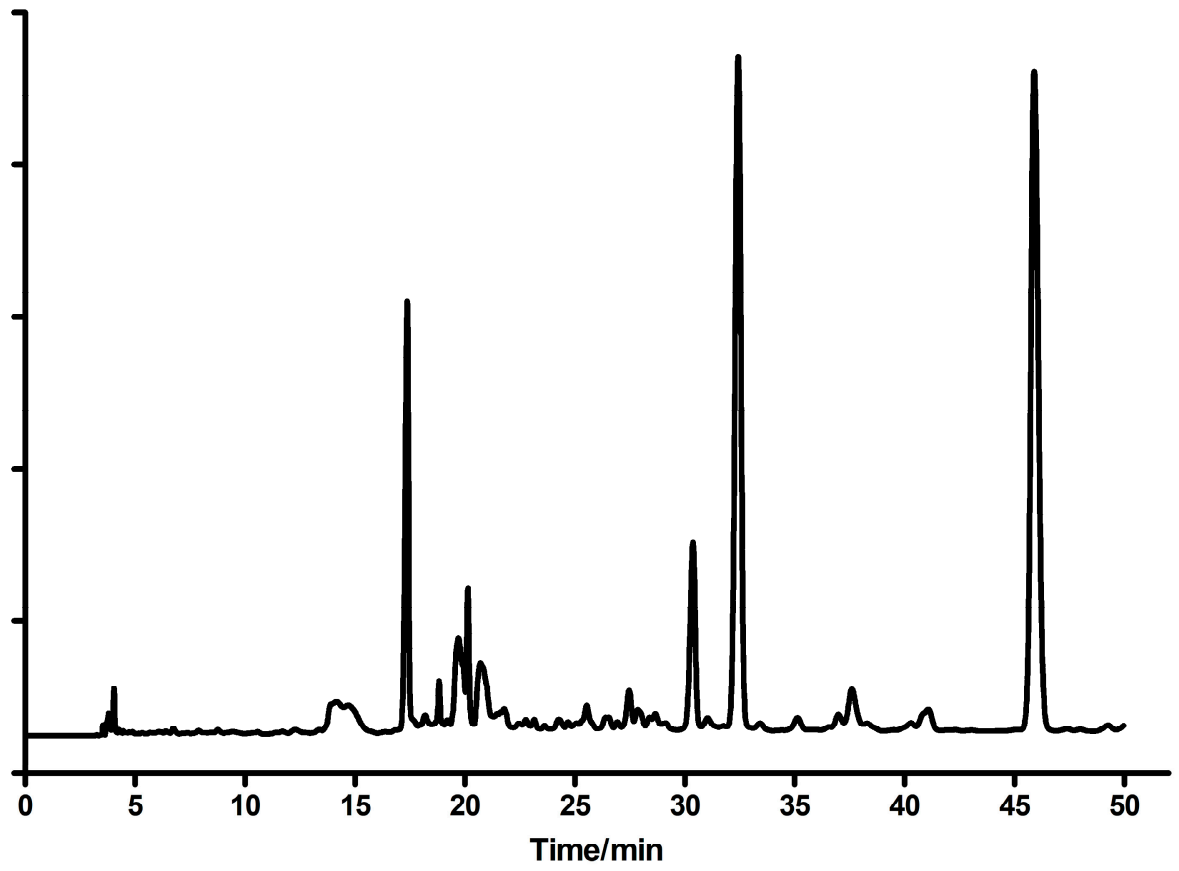

Figure 10. The HPLC elution profile of the post-reaction mixture (2-amino-6-chloropurine riboside reacting with chloroacetaldehyde). Based on UV and fluorescence spectra, the peak at 17 min was identified as guanine, at $30 \mathrm{~min}$ as $\mathrm{N}^{2}, 3$-ethenoguanine (2), at $32 \mathrm{~min}$ as $1, N^{2}$-ethenoguanine (1), and that of $46 \mathrm{~min}$ as $1, N^{2}$-ethenoguanosine. A small amount of the starting substance, 2-amino-6-chloropurine riboside, is not envisioned (retention time $>50 \mathrm{~min}$ ).

$N^{2}$,3-etheno- $O^{6}$-methylguanine (3) was obtained from the reaction of aqueous CAA with $\mathrm{O}^{6}$-methylguanine under weakly acidic conditions (ca. 3 days). There was essentially one product, easily crystallized after the neutralization of the reaction mixture. Demethylation of $N^{2}$,3-etheno- $\mathrm{O}^{6}$-methylguanine (3) in boiling $1 \mathrm{~N} \mathrm{HCl}[3]$ led to $\mathrm{N}^{2}$,3-ethenoguanine (2), identical to the previously obtained sample (see above).

Etheno derivatives of isoguanine (2-hydroxy-6-aminopurine) and isoguanosine were prepared in analogous ways, but the nucleoside was somewhat more reactive (reaction time was $2-3$ days) then the base ( 7 days). In both cases only a single product, easily identified as the $1, N^{6}$-etheno derivative, was obtained and purified using semi-preparative HPLC with methanol gradient as the main eluent (see Supplementary Materials).

The detailed procedure for (4): Isoguanine $(200 \mathrm{mg}$ ) dissolved initially in $\sim 10 \mathrm{~mL}$ of $1 \mathrm{M} \mathrm{HCl}$, added $1 \mathrm{~mL}$ of aqueous CAA, reaction $\mathrm{pH}$ elevated to $\sim 2$ by addition of bicarbonate, and left overnight. The next day, the reaction $\mathrm{pH}$ elevated to $\sim 3$, and after $24 \mathrm{~h}$ to $4-4.5$ and was maintained by bicarbonate and/or acetic acid. After 7 days the crude precipitate was collected and dried. HPLC analysis showed $\sim 70 \%$ progress of the reaction. The crude precipitate was used as such for the ribosylation experiments and aliquot purified using HPLC.

General procedure for milligram-scale enzymatic syntheses of $\varepsilon$ isoGua (4) ribosides is as follows: $10 \mathrm{mg}$ of substrate dissolved in diluted aqueous ammonia (ca. $10 \mathrm{~mL}$ ) and stepwise added to ca. $5 \mathrm{~mL}$ of $100 \mathrm{mM}$ HEPES buffer, $\mathrm{pH} 7$, containing ca. $10 \mathrm{mM}$ solution of R1P and $20 \mu \mathrm{L}$ of concentrated $(\sim 2.6 \mathrm{mg} / \mathrm{mL})$ E. coli PNP. The reaction was carried out at $30{ }^{\circ} \mathrm{C}$ for 3 days, the mixture concentrated, and products separated as described below. Typical HPLC profiles are shown on Figure 11. 


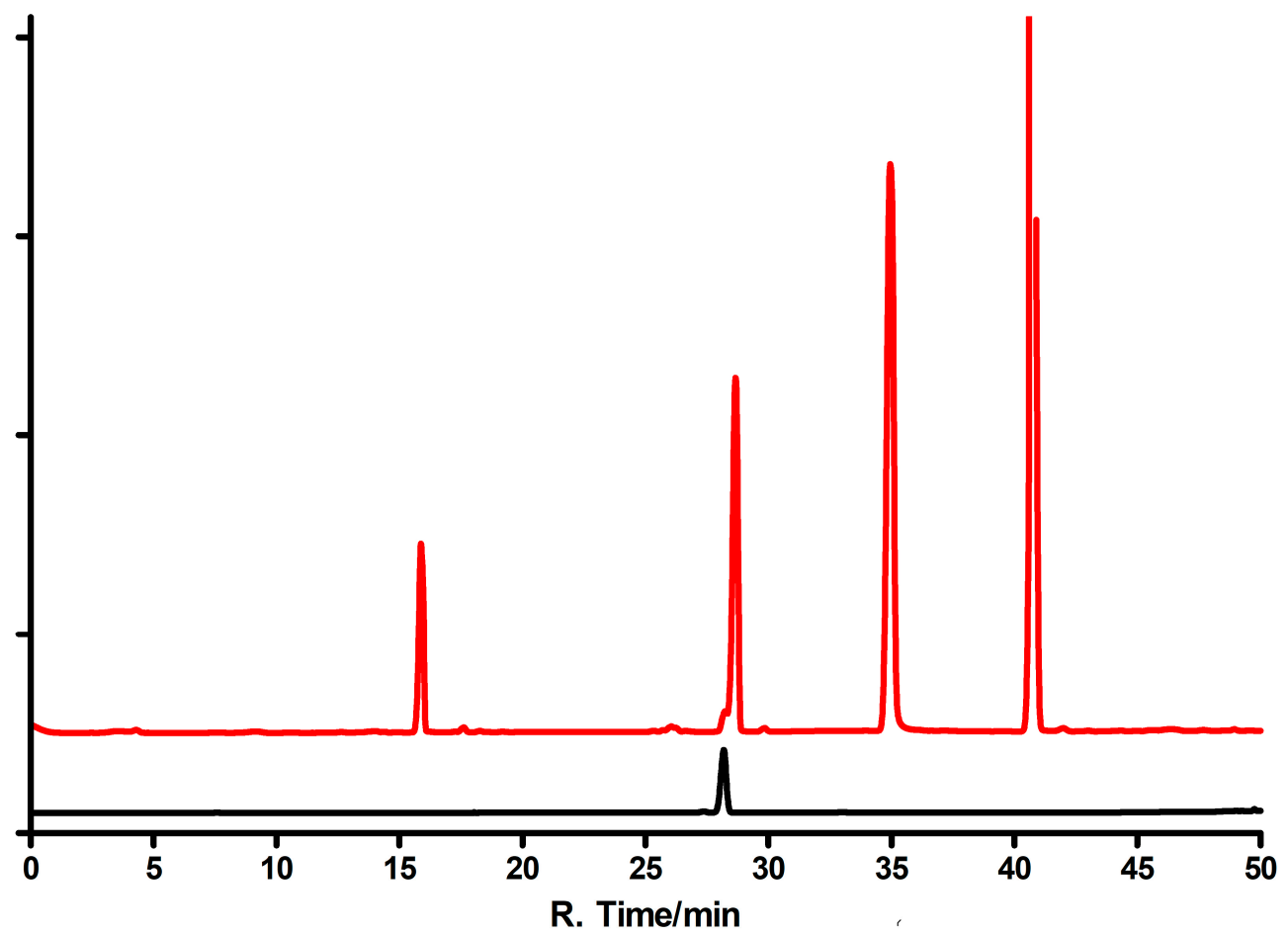

Figure 11. HPLC elution profiles of the reaction mixtures resulting from enzymatic syntheses of the ribosides of $1, N^{6}$-ethenoisogusanine (4). Upper curve: The reaction catalyzed by the E. coli PNP; lower curve: The reaction catalyzed by calf PNP. The peak with the retention time of $15 \mathrm{~min}$ is isoguanine; 28 min indicates either $N 9$-riboside (5, upper curve) or $N^{6}$-riboside $(7$, lower curve); 35 min indicates substrate (4), and $\sim 44 \mathrm{~min}$ is the $N 7$ riboside (6). Elution program: 0-15 min water, $15-45$ min methanol gradient $10-30 \%$.

Product separation and purification used HPLC on a UFLC system from Shimadzu (Kyoto, Japan) equipped with UV (diode-array) detection at 260, 280 and $315 \mathrm{~nm}$, and a fluorescence detector. The column used was a Kromasil reversed-phase a semi-preparative C-18 column $(250 \times 10 \mathrm{~mm}, 5-\mu \mathrm{m}$ particle size). Elution was initially $(10-15 \mathrm{~min})$ isocratic, followed by water-methanol gradient (usually $10-30 \%$ methanol for $35-40 \mathrm{~min}$ ).

For kinetic analyses, enzymatic ribosylation reactions were carried out in $1 \mathrm{~mL}$ cuvettes (pathlength $4 \mathrm{~mm}$ ) in $~ 50 \mathrm{mM}$ HEPES buffer, pH 7.3, using ca. $0.5 \mathrm{mM}$ R1P as a ribose source. On a larger scale, reactions were run in Eppendorf tubes, volume 2-3 mL, using either R1P or 7-methylguanosine as ribose sources. Phosphorolysis reactions were run in $50 \mathrm{mM}$ phosphate buffer, $\mathrm{pH} 7.0$ or 6.5. Data were analyzed by standard methods (see Supplementary Materials).

Fluorescence spectra were measured on a Varian Eclipse instrument (Varian Corp., Palo Alto, CA, USA), and UV absorption kinetic experiments were performed on a Cary 5000 (Varian) thermostated spectrophotometer. Fluorescence yields were determined relative to tryptophan (0.15) or $1, N^{6}$-ethenoadenosine in water $(0.56,[2])$. Spectra were measured in semi-micro cuvettes, pathlength $4 \mathrm{~mm}$, to diminish the inner-filter effect. Fluorescence decay was measured and analyzed using a FluoTime 200 lifetime fluorometer (PicoQuant GmbH, Germany), equipped with an R3809U-50 microchannel-plate photomultiplier (MCP-PMT, Hamamatsu, Japan), with $280 \mathrm{~nm}$ excitation by sub-nanosecond pulsed LED, as previously described [39]. All buffers were of analytical grade and show no fluorescence background.

NMR measurements were performed on a Bruker Avance III HD $800 \mathrm{MHz}$ spectrometer equipped with a cryogenically-cooled $\mathrm{H}-\mathrm{C} / \mathrm{N}-\mathrm{D}$ TCI probe at $25^{\circ} \mathrm{C}$ (sample identified as $\mathrm{N}^{7}$ riboside) or $50{ }^{\circ} \mathrm{C}$ (the other two samples). For all samples the following spectra were acquired: A standard proton spectrum, a ${ }^{1} \mathrm{H},{ }^{1} \mathrm{H}$ gradient selected COSY, a gradient selected ${ }^{1} \mathrm{H},{ }^{13} \mathrm{C}$ HSQC and a gradient selected 
${ }^{1} \mathrm{H},{ }^{13} \mathrm{C}$ HMBC tuned for $7 \mathrm{~Hz} \mathrm{~J}$ coupling with a double low pass J filter. For the sampled identified as the N7-riboside a gradient selected ${ }^{1} \mathrm{H}$, the ${ }^{15} \mathrm{~N}$ HMBC experiment tuned for $15 \mathrm{~Hz} \mathrm{~J}$ coupling was also acquired.

${ }^{1} \mathrm{H}$ chemical shift was referenced by the field-locked substitution method using a $<1 \%$ sample of TMS in DMSO-d6, ${ }^{13} \mathrm{C}$ and ${ }^{15} \mathrm{~N}$ chemical shifts were referenced using the unified chemical shift scale [40]. 2D spectra were processed using the TopSpin $3.5 \mathrm{pl} 7$ software package (Bruker) and inspected using the Sparky program [41] with manual peak-picking.

Recombinant E. coli and calf spleen PNPs as well as their mutated forms were expressed in E. coli and purified according to the procedures described earlier $[42,43]$.

\section{Conclusions}

A known chemical mutagen and carcinogen, vinyl chloride, acts as a modifier of nucleobases, in particular, adenine and guanine moieties [12], which upon extending the heterocyclic system change the respective coding properties $[21,25,44]$. We have found that at least in bacteria the modified nucleosides can be further degraded by the bacterial PNP, the fact that may account for bacteria's resistance to mutagenesis, together with the confirmed role of the bacterial glycosylases [45] and deoxyribosyl-transferases [45,46] in this process. PNP may have also some role in the metabolism of the rare t-RNA component, the Y-base and its nucleoside, wyosine.

Another important application of PNP is in chemo-enzymatic synthesis of bioactive nucleoside analogs, utilizing, among others, various types of PNP [14,16,17,46,47]. This application may be extended to tri-cyclic nucleobase analogs, particularly to adenine, isoguanine, and guanine derivatives. As shown in this and the previous [18] works, various forms of PNP are able to synthesize ribosides of such extended nucleobase analogs. In particular, $N 9-\beta$-D-riboside of (1) can be obtained quantitatively from (1), and N9- $\beta$-D- and N7- $\beta$-D-ribosides of (4) as a mixture, using the E. coli PNP as a biocatalyst. Additionally, a non-typical $N^{6}-\beta$-D-riboside (7) of $\varepsilon$ isoGua (4) can be nearly quantitatively obtained from (4) using the calf enzyme.

The next work (in preparation) shows that also various etheno-derivatives of the amino-purines, including etheno-2-aminopurine isomers, readily react with PNP to give various ribosides. The above results indicate need for further investigations on the enzymatic ribosylation of various nucleobase analogs to improve specificity and yields. Since the number of the known molecular forms of PNP (natural and mutated) is large $[13,16]$, there is a good chance to obtain specific and efficient biocatalysts for a given task.

Finally, attention should be drawn to the new, highly fluorescent nucleoside analogs, derived from mutagenic $\mathrm{O}^{6}$-methylguanine and isoguanine. These compounds may be good candidates for the study of ligand-binding equillibria using various PNP forms and for analytical applications.

Supplementary Materials: The following are available online, Figure S1: Time-dependence of fluorescence intensity (blue: at $400 \mathrm{~nm}$; yellow: at $460 \mathrm{~nm}$ ) measured during the ribosylation of $N^{2}, 3$-etheno- $O^{6}$-methylguanine $(35 \mu \mathrm{M})$ with R1P $(0.5 \mathrm{mM})$ as a ribosyl donor, with $E$. coli PNP as a catalyst., at $\mathrm{pH} 7.3$ and temperature $25^{\circ} \mathrm{C}$. In red color, solid line: a theoretically calculated progress curve, assuming $\mathrm{K}_{\mathrm{m}}=7 \mu \mathrm{M}$ and Michaelis'-Menten kinetics. Fluorescence excitation was at $290 \mathrm{~nm}$. Figure S2: Spectrophotometric titrations of $1, N^{6}$-etheno-isoguanine. Left: determination of the lower (basic) pKa value: $\mathrm{pH}$ values from 2.9 (red) to 5.5 (violet); Right: determination of the upper (acidic) pK value: $\mathrm{pH}$ from 6.25 (red) to 11.5 (violet). The fitted $\mathrm{pK}_{\mathrm{a}}$ values: 3.5 and $8.1( \pm 0.2)$. Figure S3: Double-reciprocal (Michaelis'-Menten) plots for ribosylation of $1, N^{2}$-ethenoguanine (right) and $1, N^{6}$-ethenoisoguanine (right), catalyzed by the E. coli PNP, wild-type. The obtained values of $\mathrm{K}_{\mathrm{m}}$ were $48 \mu \mathrm{M}$ and $98 \mu \mathrm{M}$, respectively. Conditions: $50 \mathrm{mM}$ HEPS buffer, $\mathrm{pH} 7.3$, with R1P $(0.5 \mathrm{mM})$ as a ribosyl donor, temperature $25^{\circ} \mathrm{C}$. Figure S4: Phosphorolysis of N7- (left) and N9- $\beta$-D- (right) ribosides of $1, N^{6}$-etheno-isoguanosine in $50 \mathrm{mM}$ phosphate buffer, $\mathrm{pH} 6.5$, at $25^{\circ} \mathrm{C}$, catalyzed by the E. coli PNP. Table S1. Assigned chemical shifts of the three ribosides of $\varepsilon$ isoGua in DMSO-d6 at $25^{\circ} \mathrm{C}$ (N7-riboside) or $50{ }^{\circ} \mathrm{C}\left(N^{6}\right.$ and N9-ribosides). Chemical shift labels follow the naming convention of [42], extended for the etheno protons (see Scheme 1). NA-resonance not assigned. For the N7 and N9-ribosides atoms in the positions 10 and 11 could not be unequivocally assigned and the two possible values are slash-separated. 
Author Contributions: A.S.-W. and J.W. are responsible for kinetic and spectroscopic measurements, and A.S.-W. additionally for HPLC analysis. M.G. is responsible for NMR spectral analysis. Enzyme cloning and purifications has been initiated and supervised by A.B. and B.W.-K. This paper was written jointly by all the authors.

Funding: This work profited from the "MINIATURA-1" grant \#DEC-2017/01/X/ST5/00807 by the NCN (National Center of Science, Cracow, Poland) and from the University of Varmia and Masuria in Olsztyn. AB and BWK thank the project BST-181100/BF and BST-185500/BF from the Polish Ministry of Science and Higher Education for the financial support. Part of this study was carried out at the Biological and Chemical Research Centre, University of Warsaw, established within a project co-financed by the European Union from the European Regional Development Fund under the Operational Programme Innovative Economy, 2007-2013, NanoFun Laboratories, ERDF Project POIG.02.02.00-00-025/09, and in the Laboratory of Biopolymers, ERDF Project POIG.02.01.00-14-122/09.

Acknowledgments: We thank Jerzy Sepioł from the Institute of Physical Chemistry, Polish Academy of Sciences, for authentic samples of isoguanine and isoguanosine and Bogdan Smyk (University of Varmia and Masuria in Olsztyn, Poland) for help in the determination of the fluorescence decay times We are also indebted to Goran Mikleuševic for preparation E. coli PNP variants used in this study.

Conflicts of Interest: The authors declare that they have no conflict of interest with the contents of this article.

\section{Abbreviations}

CAA; chloroacetic aldehyde; COSY; Correlation spectroscopy; DMSO-d6; Hexadeuterodimethyl sulfoxide; $\varepsilon$ Ado; 1, $N^{6}$-ethenoadenosine; $\varepsilon$ isoGua: 1, $N^{6}$-ethenoisoguanine; HMBC; Heteronuclear multiple-bond correlation; HPLC; high-performance liquid chromatography; HSQC; Heteronuclear single-quantum correlation; Isoguanine; isoGua; 2-hydroxy-6-aminopurine; Isoguanosine; N9- $\beta$-D-ribosyl- of the foregoing; NMR; Nuclear magnetic resonance; R1P: $\alpha$-D-ribose-1-phoshate; TMS; tetramethylsilane.

\section{References}

1. Leonard, N.J. Adenylates: Bound and unbound. Biopolymers 1985, 24, 9-28. [CrossRef] [PubMed]

2. Leonard, N.J. Etheno-substituted nucleotides and coenzymes: Fluorescence and biological activity. CRC Crit. Revs. Biochem. 1984, 15, 125-199. [CrossRef]

3. Sattsangi, P.D.; Leonard, N.J.; Frihart, C.R. 1, $\mathrm{N}^{2}$-ethenoguanine and $\mathrm{N}^{2}, 3$-ethenoguanine: Synthesis and comparison of the electronic spectral properties of these linear and angular triheterocycles related to the $\mathrm{Y}$ bases. J. Org. Chem. 1977, 42, 3292-3296. [CrossRef] [PubMed]

4. Sattsangi, P.D.; Barrio, J.R.; Leonard, N.J. 1,N6 - etheno bridged adenines and adenosines. Alkyl substitution, fluorescence properties, and synthetic applications. J. Am. Chem. Soc. 1980, 102, 770-774. [CrossRef]

5. Boryski, J. 1, $\mathrm{N}^{2}$-ethenoguanosine: Three methods of synthesis. Nucleosides Nucleotides Nucleic Acids 1990, 9 , 803-813. [CrossRef]

6. Hořejši, K.; Pohl, R.; Holy, A. Tricyclic Purine Analogs Derived from 2-Amino-6-chloropurine and 2,6-Diaminopurine and Their Methylated Quaternary Salts. Coll. Czech. Chem. Commun. 2006, 71, 77-90. [CrossRef]

7. Virta, P.; Holmstrom, T.; Roslund, M.U.; Mattjus, P.; Kronberg, L.; Sjoholm, R. New nucleoside analogs from 2-amino-9-( $\beta$-D-ribofuranosyl)-purine. Org. Biomol. Chem. 2004, 2, 821-827. [CrossRef] [PubMed]

8. Virta, P.; Koch, A.; Roslund, M.U.; Mattjus, P.; Kleinpeter, E.; Kronberg, L.; Sjoholm, R.; Klika, K.D. Synthesis, characterisation and theoretical calculations of 2,6-diaminopurine etheno derivatives. Org. Biomol. Chem. 2005, 3, 2924-2929. [CrossRef] [PubMed]

9. Golankiewicz, B.; Ostrowski, T. Tricyclic nucleoside analogues as antiherpes agents. Antiviral Res. 2006, 71 , 134-140. [CrossRef]

10. Jahnz-Wechmann, Z.; Framski, G.R.; Januszczyk, P.A.; Boryski, J. Bioactive fused heterocycles: Nucleoside analogs with an additional ring. Eur. J. Med. Chem. 2015, 97, 388-396. [CrossRef]

11. Jahnz-Wechmann, Z.; Framski, G.R.; Januszczyk, P.A.; Boryski, J. Base-modified nucleosides: Etheno derivatives. Front. Chem. 2016, 4, 19-29. [CrossRef] [PubMed]

12. Singer, B.; Kuśmierek, J.T. Chemical mutagenesis. Annual Rev. Biochem. 1982, 51, 655-693. [CrossRef]

13. Bzowska, A.; Kulikowska, E.; Shugar, D. Purine nucleoside phosphorylases: Properties, functions, and clinical aspects. Pharmacol. Ther. 2000, 88, 349-425. [CrossRef]

14. Wierzchowski, J.; Stachelska-Wierzchowska, A.; Wielgus-Kutrowska, B.; Bzowska, A. 1, $\mathrm{N}^{6}$-ethenoadenine and other fluorescent nucleobase analogues as substrates for purine-nucleoside phosphorylases: Spectroscopic and kinetic studies. Curr. Pharm. Des. 2017, 23, 6972-6990. 
15. Mikhailopulo, A.I.; Miroshnikov, A.I. Biologically important nucleosides: Modern trends in biotechnology and application. Mendeleev Commun. 2011, 21, 57-68. [CrossRef]

16. Kamel, S.; Yehia, H.; Neubauer, P.; Wagner, A. Chapter 1. In Enzymatic and Chemical Synthesis of Nucleic Acid Derivatives; Fernandez-Lucas, J., Camarasa-Rius, M.J., Eds.; Wiley-VCH: Weinheim, Germany, 2019.

17. Yehia, H.; Kamel, S.; Paulick, K.; Neubauer, P.; Wagner, A. Substrate Spectra of Nucleoside Phosphorylases and their Potential in the Production of Pharmaceutically Active Compounds. Curr. Pharm. Des. 2017, 23, 6913-6935. [CrossRef] [PubMed]

18. Stachelska-Wierzchowska, A.; Wierzchowski, J.; Bzowska, A.; Wielgus-Kutrowska, B. Tricyclic nitrogen base, 1, $\mathrm{N}^{6}$-Ethenoadenine, and its Ribosides, as Substrates for Purine-Nucleoside Phosphorylases: Spectroscopic and Kinetic Studies. Nucleosides Nucleotides Nucleic Acids 2018, 37, 89-101. [CrossRef] [PubMed]

19. Schramm, V.L. Transition states, analogues, and drug development. ACS Chem. Biol. 2013, 8, 71-81. [CrossRef]

20. Kusmierek, J.T.; Singer, B. 1, $\mathrm{N}^{2}$-ethenodeoxyguanosine-Properties and formation in chloroacetaldehyde-treated polynucleotides and DNA. Chem. Res. Toxicol. 1992, 25, 634-638. [CrossRef]

21. Patra, A.; Su, Y.; Zhang, Q.Q.; Johnson, K.M.; Guengerich, F.P.; Egli, M. Structural and Kinetic Analysis of Miscoding Opposite the DNA Adduct 1, $\mathrm{N}^{6}$-Ethenodeoxyadenosine by Human Translesion DNA Polymerase. J. Biol. Chem. 2016, 291, 14134-14145. [CrossRef]

22. Choi, J.Y.; Zang, H.; Angel, K.C.; Kozekov, I.D.; Goodenough, A.K.; Rizzo, C.J.; Guengerich, F.P. Translesion synthesis across 1, $\mathrm{N}^{2}$-ethenoguanine by human DNA polymerases. Chem. Res. Toxicol. 2006, 19, 879-886. [CrossRef] [PubMed]

23. Kusmierek, J.T.; Jensen, D.; Spengler, S.J.; Stolarski, R.; Singer, B. Synthesis and properties of $\mathrm{N}^{2}$,3-ethenoguanosine and $\mathrm{N}^{2}$,3-ethenoguanosine 5'-diphosphate. J. Org. Chem. 1987, 52, 2374-2378. [CrossRef]

24. Chang, S.C.; Fedeles, B.I.; Wu, J.; Delaney, J.C.; Li, D.Y.; Zhao, L.L.; Christov, P.P.; Yau, E.; Singh, V.; Jost, M. Next-generation sequencing reveals the biological significance of the $\mathrm{N}^{2}, 3$-ethenoguanine lesion in vivo. Nucleic Acids Res. 2015, 43, 5489-5500. [CrossRef] [PubMed]

25. Zhao, L.L.; Pence, M.G.; Christov, P.P.; Wawrzak, Z.; Choi, J.Y.; Rizzo, C.J.; Egli, M.; Guengerich, F.P. Basis of Miscoding of the DNA Adduct $\mathrm{N}^{2}, 3$-Ethenoguanine by Human Y-family DNA Polymerases. J. Biol. Chem. 2012, 287, 35516-35526. [CrossRef] [PubMed]

26. Yarosh, D.B. The role of $\mathrm{O}^{6}$-methylguanine-DNA methyltransferase in cell survival, mutagenesis and carcinogenesis. Mutat. Res. 1985, 145, 1-16. [CrossRef]

27. Rasouli-Nia, A.; Sibghat-Ullah; Mirzayans, R.; Paterson, M.C.; Day, R.S. On the quantitative relationship between $\mathrm{O}^{6}$-methylguanine residues in genomic DNA and production of sister-chromatid exchanges, mutations and lethal events in a Mer- human tumor cell line. Mutat. Res. 1994, 314, 99-113. [CrossRef]

28. Sepioł, J.; Kazimierczuk, Z.; Shugar, D. Tautomerism of isoguanosine and solvent-induced keto-enol equilibrium. Z. Naturforsch. 1976, 31c, 361-370. [CrossRef]

29. Cheng, Q.; Compaan, K.R.; Schaffer, H.F., III. Isoguanine formation from adenine. Chem. Eur. J. 2012, 18, 4877-4886. [CrossRef]

30. Bukowska, A.M.; Kusmierek, J.T. Miscoding properties of isoguanine (2-oxoadenine) studied in an AMV reverse transcriptase in vitro system. Acta Biochim. Polon. 1996, 43, 247-254.

31. Kemena, A.; Fernandez, M.; Bauman, J.; Keating, M.; Plunkett, W. A sensitive fluorescence assay for quantitation of fludarabine and metabolites in biological-fluids. Clin. Chim. Acta 1991, 200, 95-106. [CrossRef]

32. Holmén, A.; Albinsson, B.; Nordén, B. Electronic transition dipole moments of the 1, $\mathrm{N}^{6}$-ethenoadenine chromophore. J. Phys. Chem. 1994, 98, 13460-13469. [CrossRef]

33. Stachelska-Wierzchowska, A.; Wierzchowski, J.; Wielgus-Kutrowska, B.; Mikleušević, G. Enzymatic synthesis of highly fluorescent 8-azapurine ribosides using purine-nucleoside phosphorylase reverse reaction: Variable ribosylation sites. Molecules 2013, 18, 12587-12598. [CrossRef]

34. Dračínský, M.; Pohl, R. NMR Studies of Purines. Annu. Rep. NMR Spectr. 2014, 82, 59-113. 
35. Markley, J.L.; Bax, A.; Arata, Y.; Hilbers, C.W.; Kaptein, R.; Sykes, B.D.; Wright, P.E.; Wüthrich, K. Recommendations for the presentation of NMR structures of proteins and nucleic acids-IUPAC-IUBMB-IUPAB Inter-Union Task Group on the standardization of data bases of protein and nucleic acid structures determined by NMR spectroscopy. J. Biomol. NMR 1998, 12, 1-23. [CrossRef] [PubMed]

36. Sinkeldam, R.W.; Greco, N.J.; Tor, Y. Fluorescent analogs of biomolecular building blocks: Design, properties, and applications. Chem. Rev. 2010, 110, 2579-2619. [CrossRef]

37. Stoeckler, J.D.; Poirot, A.F.; Smith, R.M.; Robert, E.; Parks, R.E.; Ealick, S.E.; Takabayashi, K.; Erion, M.D. Purine nucleoside phosphorylase. 3. Reversal of purine base specificity by site-directed mutagenesis. Biochemistry 1997, 36, 11749-11756. [CrossRef]

38. Stachelska-Wierzchowska, A.; Wierzchowski, J.; Bzowska, A.; Wielgus-Kutrowska, B. Site-selective ribosylation of fluorescent nucleobase analogs using purine-nucleoside phosphorylase as a catalyst: Effects of point mutations. Molecules 2016, 21, 44. [CrossRef]

39. Wierzchowski, J.; Mędza, G.; Szabelski, M.; Stachelska-Wierzchowska, A. Properties of 2,6-diamino-8-azapurine, a highly fluorescent purine analog and its $\mathrm{N}$-alkyl derivatives: Tautomerism and excited-state proton transfer reactions. J. Photochem. Photobiol. 2013, 265, 49-57. [CrossRef]

40. Harris, R.K.; Becker, E.D.; De Menezes, S.M.C.; Granger, P.; Hoffman, R.E.; Zilm, K.W. Further conventions for NMR shielding and chemical shifts (IUPAC Recommendations 2008). Pure Appl. Chem. 2008, 80, 59-84. [CrossRef]

41. Goddard, T.D.; Kneller, D.G. SPARKY 3; University of California: San Francisco, CA, USA, 2000.

42. Mikleuševic, G.; Štefanic, Z.; Narczyk, M.; Wielgus-Kutrowska, B.; Bzowska, A.; Luic, M. Validation of the catalytic mechanism of Escherichia coli purine nucleoside phosphorylase by structural and kinetic studies. Biochimie 2011, 93, 1610-1622. [CrossRef]

43. Breer, K.; Girstun, A.; Wielgus-Kutrowska, B.; Staron, K.; Bzowska, A. Overexpression, purification and characterization of functional calf purine nucleoside phosphorylase (PNP). Prot. Expr. Purif. 2008, 61, 122-130. [CrossRef] [PubMed]

44. Calabretta, A.; Leumann, C.J. Base pairing and miscoding properties of $1, \mathrm{~N}^{6}$-ethenoadenine- and 3, $\mathrm{N}^{4}$-ethenocytosine-containing RNA oligonucleotides. Biochemistry 2013, 52, 1990-1997. [CrossRef] [PubMed]

45. Maciejewska, A.M.; Sokolowska, B.; Nowicki, A.; Kusmierek, J.T. The role of AlkB protein in repair of 1, $\mathrm{N}^{6}$-ethenoadenine in Escherichia coli cells. Mutagenesis 2011, 26, 401-406. [CrossRef]

46. Mikhailopulo, I.A. Biotechnology of nucleic acid components-State of the art and perspectives. Curr. Org. Chem. 2007, 11, 317-335. [CrossRef]

47. Ye, W.; Paul, D.; Gao, L.; Seckute, J.; Sangaiah, R.; Jayaraj, K.; Zhang, Z.; Kaminski, P.A.; Ealick, S.E.; Gold, A.; Ball, L.M. Ethenoguanines Undergo Glycosylation by Nucleoside 29-Deoxyribosyltransferases at Non-Natural Sites. PLoS ONE 2014, 9, e115082. [CrossRef] [PubMed]

(C) 2019 by the authors. Licensee MDPI, Basel, Switzerland. This article is an open access article distributed under the terms and conditions of the Creative Commons Attribution (CC BY) license (http://creativecommons.org/licenses/by/4.0/). 